Short Communication

\title{
The complete mitochondrial genome of the threatened Neotropical catfish Lophiosilurus alexandri (Silurifomes: Pseudopimelodidae) and phylogenomic analysis indicate monophyly of Pimelodoidea
}

\author{
Daniel Cardoso Carvalho ${ }^{1}$, Violeta da Rocha Perini ${ }^{2}$, Alex Schomaker Bastos ${ }^{2 *}$, Igor Rodrigues da Costa ${ }^{2}$, \\ Ronald Kennedy Luz ${ }^{3}$, Carolina Furtado ${ }^{4}$ and Francisco Prosdocimi ${ }^{2}$ \\ ${ }^{1}$ Laboratório de Genética da Conservação, Programa de Pós-Graduação em Biologia dos Vertebrados, \\ Pontifícia Universidade Católica de Minas Gerais (PUC Minas), Belo Horizonte, MG, Brazil. \\ ${ }^{2}$ Laboratório de Genômica e Biodiversidade, Instituto de Bioquímica Médica Leopoldo de Meis, \\ Universidade Federal do Rio de Janeiro (UFRJ), Rio de Janeiro, RJ, Brazil. \\ ${ }^{3}$ Laboratório de Aquacultura da Escola de Veterinária da Universidade Federal de Minas Gerais (UFMG, \\ Belo Horizonte, MG, Brazil. \\ ${ }^{4}$ Instituto Nacional do Câncer (INCA), Rio de Janeiro, RJ, Brazil.
}

\begin{abstract}
Lophiosilurus alexandri is an endemic catfish from the São Francisco River Basin (Brazil) popularly known as pacamã, which has economic potential for aquaculture farming. The mitochondrial genome was sequenced for the threatened Neotropical catfish L. alexandri. Assembly into scaffolds using MIRA and MITObim software produced the whole, circularized mitochondrial genome, which comprises 16,445 bp and presents the typical gene arrangement of Teleostei mitochondria. A phylogenomic analysis was performed after the concatenation of all proteins obtained from whole mitogenomes of 20 Siluriformes and two outgroups. The results confirmed the monophyly of nine families of catfishes and also clustered $L$. alexandri as a sister group to the family Pimelodidae, thus confirming the monophyly of the superfamily Pimelodoidea. This is the first mitochondrial phylogenomics study for Pimelodoidea and the first mitogenome described for the Pseudopimelodidae family, representing an important resource for phylogeography, evolutionary biology, and conservation genetics studies in Neotropical fishes.
\end{abstract}

Keywords: Mitogenome, fish, next-generation-sequencing, Illumina, Pseudopimelodidae.

Received: January 19, 2016; Accepted: June 20, 2016.

Catfishes (Siluriformes) are a highly diverse order composed of 39 families and more than 3,700 living species (Eschmeyer and Fong, 2016). The fish Lophiosilurus alexandri (Steindachner, 1877), popularly known as pacamã, is an endemic catfish from the São Francisco River Basin (Brazil) and belongs to the Pseudopimelodidae family, a taxon broadly distributed in South America (Eschmeyer and Fong, 2016). L. alexandri is a carnivorous species that displays parental care and has economic potential for aquaculture farming (Sato et al., 2003; dos Santos and Luz, 2009).

Pacamã may be cultivated in captivity after adapting broodstock to aquaculture conditions (Costa et al., 2015),

Send correspondence to Daniel C. Carvalho. Laboratório de Genética da Conservação, Programa de Pós-Graduação em Biologia dos Vertebrados, Pontifícia Universidade Católica de Minas Gerais (PUC Minas), Av. Dom José Gaspar, 500, Coração Eucarístico 30535-901 - Belo Horizonte, MG, Brazil. Email: danielcarvalho@pucminas.br

*In memoriam (08/01/2015) however its natural populations have declined over the last decades. Threats such as overfishing and environmental degradation led to the inclusion of L. alexandri in the Brazilian red list of threatened species (Brasil, 2014).

Here we present the complete, circularized version of the whole mitochondrial genome and the phylogenomic relationships of pacamã to 20 other related Siluriformes and two outgroups using a supermatrix approach.

Muscle fragments were obtained from a freshly captured $L$. alexandri. The voucher specimen was fixed in $10 \%$ formalin and later preserved in 70\% ethanol. (voucher: LGC6088 at PUC Minas Natural History Museum). Genomic DNA was extracted using a modified salting-out method (Sunnucks and Hales, 1996) and nebulized for 6 min to obtain 200-600 bp fragments.

Partial genome sequencing was carried out using a Nextera kit in a sixth of an Illumina HiSeq 2000 lane. An initial mitogenome assembly generated by MIRA was used as an input for the MITObim algorithm (Hahn et al., 2013) using default parameters. Mitogenome coverage was ob- 
tained using Tablet software (Milne et al., 2013). Mitos WebServer (Bernt et al., 2013) and MitoFish (Iwasaki et al., 2013) were used for annotation. Blast searches (Altschul et al., 1997) against fish amino acid sequences confirmed gene boundaries. tRNA predictions were confirmed using tRNAscan-SE (Lowe and Eddy, 1997). Ribosomal RNA annotations were estimated through automatic analysis provided by Mitos Web Server and MitoFish followed by visual inspection of nucleotide sequence alignments against other Pimelodidae rRNAs.

The complete mitochondrial genome for $L$. alexandri was assembled using $0.06 \%$ (203,036 reads) of the total paired-end reads sequenced $(33,839,478$ reads of $100 \mathrm{bp}$ each). The assembly provided a circular mitogenome with $134.1 \times$ coverage comprised $16,445 \mathrm{bp}$, a size similar to the average mitogenome of catfishes. Its gene content also followed the typical pattern for teleost mitogenomes (Prosdocimi et al., 2012, Song et al., 2012, Zhang et al., 2013, Perini et al., 2014), being composed of 37 genes, including 13 protein-coding genes, 22 tRNAs, 2 rRNAs, and 1 noncoding control region (Table S1, Supplementary Material). The mitogenome of Lophiosilurus alexandri is available in GenBank under the accession number KJ494387.
An in-house pipeline developed in Python (https://github.com/igorrcosta/phylomito) was used to: (i) concatenate individual alignments of mitochondrial proteins, (ii) retrotranslate these alignments into codons/nucleotides, and (iii) provide a supermatrix dataset that has been used as input into MEGA 7 for modeltest and phylogeny reconstruction (Kumar et al., 2016).

The phylogenetic relationship between $L$. alexandri and the other 20 catfishes and two outgroups from the Gymnotiformes and Characiformes orders (Table 1) was recovered using a supermatrix approach of 11,468 nucleotides produced after the concatenation and reverse translation of protein sequence alignments for all the 13 mitochondrial proteins. A maximum likelihood tree was generated using all alignment sites with the best model found by MEGA $(\mathrm{GTR}+\mathrm{G}+\mathrm{I})$. The phylogenomic analysis produced a consistent tree in accordance with phylogenetic evidence obtained using rag 1 and rag2 nuclear genes recovered using 3,660 base pairs (Sullivan et al., 2006). Whole mitochondrial data, however, also evidenced new features, such as (i) a more ancestral split of Amblycipitidae species and also (ii) a highly supported clade (bootstrap=93) grouping families Ictaluridae, Cranogladidae and Pangasidae. $L$. alexandri, Pimelodus pictus and two species from the ge-

Table 1 - List of species, taxonomic information and accession numbers used in the phylogenetic analyses.

\begin{tabular}{|c|c|c|c|c|c|}
\hline Order & Family & Species & GenBank ID & Size (bp) & Reference \\
\hline Siluriformes & Doradidae & Amblydoras gonzalezi & NC_015745.1 & 16505 & Nakatani et al., 2011 \\
\hline Siluriformes & Doradidae & Platydoras armatulus & NC_025585.1 & 16470 & Liu et al., 2016 \\
\hline Siluriformes & Cranoglanididae & Cranoglanis bouderius & NC_008280.1 & 16539 & Peng et al., 2006 \\
\hline Siluriformes & Clariidae & Clarias sp. & NC_015749.1 & 16508 & Nakatani et al., 2011 \\
\hline Siluriformes & Clariidae & Clarias fuscus & NC_023924.1 & 16518 & Zhou et al., 2015 \\
\hline Siluriformes & Ictaluridae & Ictalurus punctatus & NC_003489.1 & 16497 & Waldbieser et al., 2003 \\
\hline Siluriformes & Ictaluridae & Ictalurus furcatus & NC_028151.1 & 16499 & Liu et al. (Unpublished) \\
\hline Siluriformes & Amblycipitidae & Liobagrus marginalis & NC_022923.1 & 16483 & Li et al., 2014 \\
\hline Siluriformes & Amblycipitidae & Liobagrus nigricauda & NC_021407.1 & 16512 & Jia et al., 2013b \\
\hline Siluriformes & Amblycipitidae & Liobagrus obesus & NC_008232.1 & 16531 & Kartavtsev et al., 2007 \\
\hline Siluriformes & Pangasiidae & Pangasianodon gigas & NC_006381.1 & 16533 & Jondeung et al., 2007 \\
\hline Siluriformes & Pangasiidae & Pangasianodon hypophthalmus & NC_021752.1 & 16522 & Zhao et al., 2014 \\
\hline Siluriformes & Pangasiidae & Pangasius larnaudii & NC_015839.1 & 16471 & Nakatani et al., 2011 \\
\hline Siluriformes & Pangasiidae & Pangasius pangasius & NC_023924.1 & 16476 & Mohindra et al., 2015 \\
\hline Siluriformes & Siluridae & Silurus glanis & NC_014261.1 & 16526 & Vitta et al., 2011 \\
\hline Siluriformes & Siluridae & Silurus meridionalis & NC_014866.1 & 16527 & Liang et al., unpublished \\
\hline Siluriformes & Siluridae & Pterocryptis conchichinensis & NC_027107.1 & 16501 & Xu et al., 2016 \\
\hline Siluriformes & Pseudopimelodidae & Lophiosilurus alexandri & KJ494387 & 16445 & Present work \\
\hline Siluriformes & Pimelodidae & Pimelodus pictus & NC_015797.1 & 16575 & Nakatani et al., 2011 \\
\hline Siluriformes & Pimelodidae & Pseudoplatystoma corruscans & NC_026846.1 & 16123 & Prosdocimi et al. (Unpublished) \\
\hline Siluriformes & Pimelodidae & Pseudoplatystoma magdaleniatum & NC_026526.1 & 16568 & Rangel-Medrano et al., 2015 \\
\hline Characiformes & Characidae & Paracheirodon axelrodi & NC_023270.1 & 17100 & Zhang et al., 2014 \\
\hline Gymnotiformes & Hypopomidae & Brachyhypopomus occidentalis & NC_015078.1 & 16542 & Lavoue et al., 2012 \\
\hline
\end{tabular}


Species Family Order

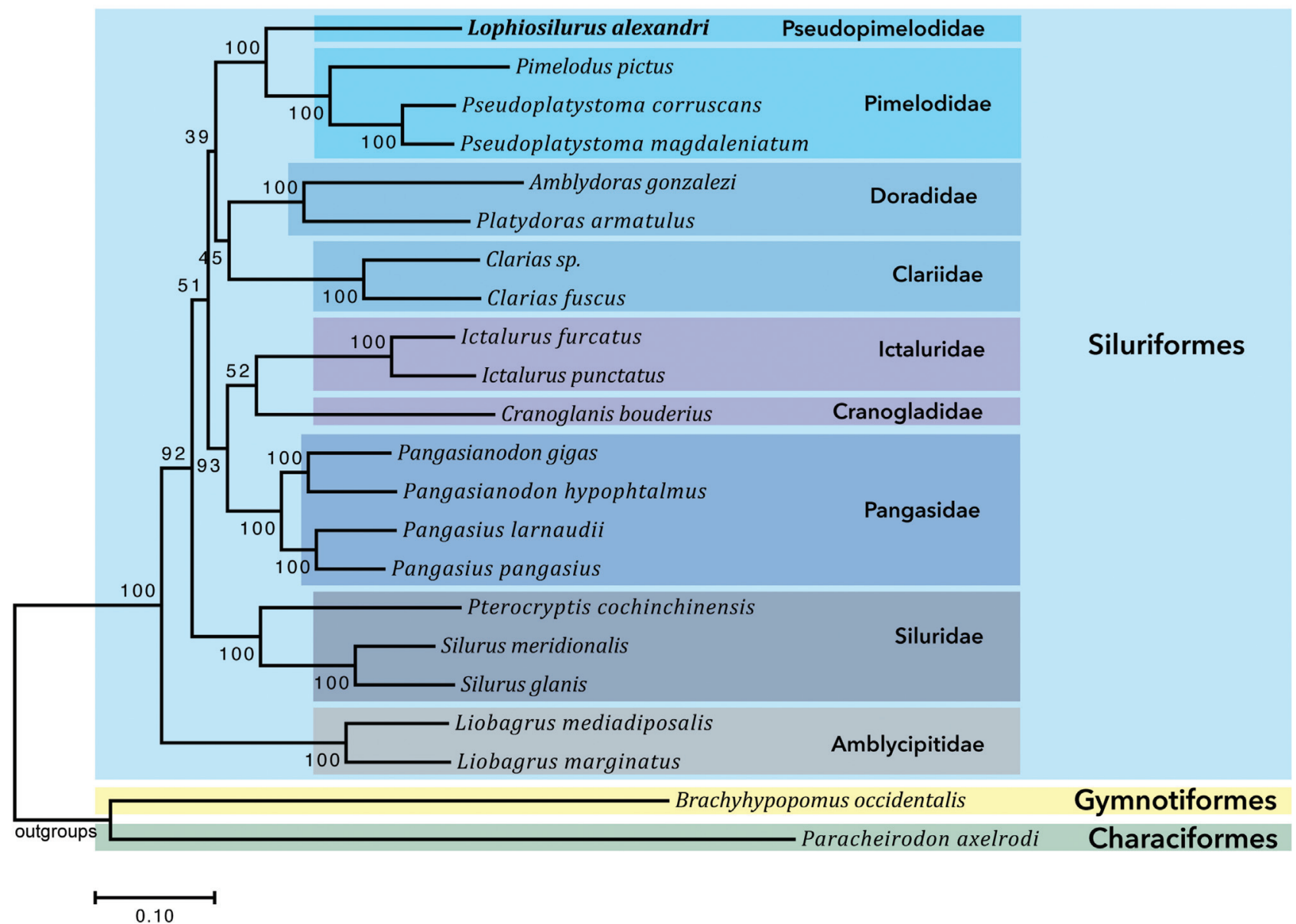

Figure 1 - Molecular phylogenetic analysis of pacamã, 20 catfishes and two outgroups. A total of 11,468 positions were analyzed consisting in the concatenation of 13 mitochondrial genes. A tree was built using maximum likelihood approaches with $\mathrm{GTR}+\mathrm{G}+\mathrm{I}$ model. Outgroups were used to root the tree. All families and genera of catfishes analyzed were revealed as monophyletic (colored boxes). Bootstrap values (1000 replicates) are shown at the corresponding nodes.

nus Pseudoplatystoma were clustered in the same clade with a very confidence support after 1000 resamplings (bootstrap=100) (Figure 1), corroborating the monophyletic relationship of the Pimelodoidea clade, as previously recovered elsewhere (Sullivan et al., 2006). The mitogenome described here is the first representative for the family Pseudopimelodidae.

\section{Acknowledgments}

The study received fincancial support from the Brazilian funding agencies FAPERJ (E-26/010.001625/2014 and E-26/202.810/2015) and CNPq (Conselho Nacional de Desenvolvimento Científico e Tecnológico; fellowship grant 308537/2014-9).

\section{References}

Altschul SF, Madden TL, Schäffer AA, Zhang J, Zhang Z, Miller W and Lipman DJ (1997) Gapped BLAST and PSI-BLAST:
A new generation of protein database search programs. Nucleic Acids Res 25:3389-3402.

Bernt M, Donath A, Jühling F, Externbrink F, Florentz C, Fritzsch G, Pütz J, Middendorf M and Stadler PF (2013) MITOS: Improved de novo metazoan mitochondrial genome annotation. Mol Phylogenet Evol 69:313-319.

Brasil (2014) Lista Nacional Oficial de Espécies da Fauna Ameaçadas de Extinção - Peixes e Invertebrados Aquáticos. Portaria MMA n ${ }^{\circ} 445$. Ministério do Meio Ambiente, Brasília, $9 \mathrm{p}$.

Costa DC, Silva WDS, Melillo Filho R, Miranda Filho KC, dos Santos JCE and Luz RK (2015) Capture, adaptation and artificial control of reproduction of Lophiosilurus alexandri: A carnivorous freshwater species. Anim Reprod Sci 159:148154.

dos Santos JCE and Luz RK (2009) Effect of salinity and prey concentrations on Pseudoplatystoma corruscans, Prochilodus costatus and Lophiosilurus alexandri larviculture. Aquaculture 287:324-328.

Hahn C, Bachmann L and Chevreux B (2013) Reconstructing mitochondrial genomes directly from genomic next-generation 
sequencing reads - A baiting and iterative mapping approach. Nucleic Acids Res 41:e129.

Iwasaki W, Fukunaga T, Isagozawa R, Yamada K, Maeda Y, Satoh TP, Sado T, Mabuchi K, Takeshima H, Miya M, et al. (2013) MitoFish and MitoAnnotator: A mitochondrial genome database of fish with an accurate and automatic annotation pipeline. Mol Biol Evol 30:2531-2540.

Kumar S, Stecher G and Tamura K (2016) MEGA7: Molecular Evolutionary Genetics Analysis version 7.0 for bigger datasets.Mol Biol Evol 33:1870-1874.

Li Q, Du J, Liu Y, Zhou J, Ke H, Liu C and Liu G (2014) The complete mitochondrial genome of Liobagrus marginatus (Teleostei, Siluriformes: Amblycipitidae). Mitochondrial DNA. 25:120-121.

Liu S, Yao J, Zhang J and Liu Z (2016) Next generation sequencing yields the complete mitochondrial genome of the striped raphael catfish, Platydoras armatulus (Siluriformes: Doradidae). Mitochondrial DNA 27:1963-1964.

Lowe TM and Eddy SR (1997) tRNAscan-SE: A program for improved detection of transfer RNA genes in genomic sequence. Nucleic Acids Res 25:0955-0964.

Milne I, Stephen G, Bayer M, Cock PJA, Pritchard L, Cardle L, Shaw PD and Marshall D (2013) Using Tablet for visual exploration of second-generation sequencing data. Brief Bioinform 14:193-202.

Mohindra V, Singh RK, Kumar R, Sah RS and Lal KK (2015) Complete mitochondrial genome sequences of two endangered Indian catfish species, Clarias batrachus and Pangasius pangasius. Mitochondrial DNA 26:678-679.

Nakatani M, Miya M, Mabuchi K, Saitoh K and Nishida M (2011) Evolutionary history of Otophysi (Teleostei), a major clade of the modern freshwater fishes: Pangaean origin and Mesozoic radiation. BMC Evol Biol 11:e177.

Perini VDR, Carvalho DC, Beheregaray LB and Prosdocimi F (2014) The complete mitochondrial genome of the southern purple-spotted gudgeon Mogurnda adspersa (Perciformes: Eleotridae) through pyrosequencing. Mitochondrial DNA 27:380-382.

Prosdocimi F, Carvalho DC, Almeida RN and Beheregaray LB (2012) The complete mitochondrial genome of two recently derived species of the fish genus Nannoperca (Perciformes, Percichthyidae). Mol Biol Rep 39:2767-2772.

Rangel-Medrano JD, Alzate JF and Márquez EJ (2015) Complete mitochondrial genome of the Neotropical catfish
Pseudoplatystoma magdaleniatum (Siluriformes, Pimelodidae). Mitochondrial DNA 28:1-2.

Sato Y, Fenerich-Verani N and Godinho HP (2003) Induced reproduction of fishes of the São Francisco. In: Godinho HP and Godinho AL (eds) Waters, Fishes, and Fishermen of the São Francisco of Minas Gerais. PUC Minas, Belo Horizonte, pp 275-290.

Song HY, Satoh TP and Mabuchi K (2012) Complete mitochondrial genome sequence of the dragonet Callionymus curvicornis (Perciformes: Callionymoidei: Callionymidae). Mitochondrial DNA 23:290-292.

Sullivan JP, Lundberg JG and Hardman M (2006) A phylogenetic analysis of the major groups of catfishes (Teleostei: Siluriformes) using rag1 and rag2 nuclear gene sequences. Mol Phylogenet Evol 41:636-662.

Sunnucks P and Hales D. (1996). Numerous transposed sequences of mitochondrial cytochrome oxidase I-II in aphids of the genus Sitobion (Hemiptera: aphididae). Mol Biol Evol 13:510-524.

Xu J, Han C and Huang JR (2016) The complete mitogenome of the sheatfish Pterocryptis cochinchinensis (Siluriformes: Siluridae) and phylogenetic implications. Mitochondr ial DNA 27:2785-2756.

Zhang Z, Zhao L, Song N and Gao T (2013) The complete mitochondrial genome of Johnius grypotus (Perciformes: Sciaenidae). Mitochondrial DNA 24:504-506.

Zhou C, Wang X, Guan L and He S (2015) The complete mitochondrial genome of Clarias fuscus (Teleostei, Siluriformes: Clariidae). Mitochondrial DNA 26:270-271.

\section{Internet Resources}

Eschmeyer WN and Fong JD (2016) Species by family/subfamily, http://researcharchive.calacademy.org/research/ichthyology/catalog/SpeciesByFamily.asp. (May 2, 2016).

\section{Supplementary Material}

The following online material is available for this article: Table S1 - Mitochondrial genome characteristics of $L$. alexandri (KJ494387).

Associate Editor: Houtan Noushmehr

License information: This is an open-access article distributed under the terms of the Creative Commons Attribution License (type CC-BY), which permits unrestricted use, distribution and reproduction in any medium, provided the original article is properly cited. 